\title{
Designed to Fail: Effects of the Default Option and Information Complexity on Student Loan Repayment
}

\author{
James C. Cox \\ Daniel Kreisman* \\ Susan Dynarski \\ Georgia State University \\ Georgia State University \\ University of Michigan
}

September 2018

\begin{abstract}
We ask why so few student loan borrowers enroll in Income Driven Repayment when the majority would benefit from doing so. To do so we run an incentivized laboratory experiment using a facsimile of the government's Student Loan Exit Counseling website. We test the role information complexity, uncertainty about earnings, and the default option play. We show that despite an ex ante optimal choice, the majority choose, or are defaulted into, a sub-optimal plan. We find the default option is a driver of this phenomenon, suggesting the government has an easy policy lever to lower default rates - change the default plan.
\end{abstract}

Keywords: Student Loans; Default Option; Income Driven Repayment; Experiment.

JEL: I22; I28; C91.

*Corresponding author(dkreisman@gsu.edu). We thank the Russell Sage Foundation for funding through its Behavioral Economics Grants program (Award \#98-16-12). 


\section{Introduction}

Behavioral economics has taught us that defining the default option, changes in framing, and increases in complexity can have substantial and costly impacts on important decisions. We have seen evidence of this with respect to healthcare (Winter et al., 2006), retirement savings (Madrian and Shea, 2001; Thaler and Benartzi, 2004), student aid (Bettinger et al., 2009; Castleman and Page, 2016), and organ donation (Johnson and Goldstein, 2003), among many others. We ask whether similar mechanisms are at play in how borrowers choose to repay their student loans.

As of 2014, one-quarter of borrowers entering repayment in 2005, 2007 or 2009 had defaulted on their student loans. To put that in perspective, within five years of exiting school roughly 25 percent of borrowers from the most recent (2009) cohort had already gone through deferment, forbearance and delinquency into default. This need not be the case. Borrowers with Direct Loans have the option to choose a repayment plan that adjusts with their earnings. Under these income driven repayment plans (IDRs), repayments are a percentage (typically 10-15\%) of discretionary income above a threshold (usually $150 \%$ of the poverty line) with an added benefit of forgiveness often after 25 years. Thus, if borrowers experience job loss or low income, small or nonexistent required repayments reflect this. In this sense these plans work as a form of insurance against low earnings in part by providing protection from default.

Yet, surprisingly few students choose one of these plans. According to the Government Accountability Office $(\mathrm{GAO})^{1}$ less than one-quarter of borrowers with Direct Loans are enrolled in some form of income driven repayment plan, with the vast majority enrolled in the Standard 10-year fixed repayment plan - the default option. A 2012 study by U.S. Department of the Treasury linking loans to tax records reached similar conclusions. Worse, Treasury found that $70 \%$ of defaulted borrowers met the criteria for enrolling in an IDR plan, which would have protected them against default. These defaults are costly. For borrowers a default affects credit scores, limiting access to future credit, and can adversely affect job prospects, potentially leading to further debt at higher interest rates. For the taxpayer, these defaults increase loan-servicing costs and directly detract from a taxpayer-subsidized program's solvency. The default rate among those who did enroll in an IDR plan, Treasury found, was less than $1 \%$.

Why are so many borrowers not enrolling in income driven repayment? Viewed through a classical framework, forward-looking borrowers with full information will make optimizing choices given their preferences for risk, consumption and expected future earnings. Low uptake of income driven repayment plans among a large number of students who both stand to benefit and qualify is one of many

\footnotetext{
${ }^{1}$ GAO $(2012,2015)$.
} 
indicators that this is not the case. We believe a behavioral explanation is more likely. We test three main hypotheses as to what might explain the surprisingly low uptake of income driven repayment plans.

First, we ask whether it is simply the power of the default option. All borrowers are automatically placed into the Standard plan and remain in that plan unless they take active steps to change. A wealth of research on other topics suggests that under these circumstances the effect of the default option should be strong. Second, we ask whether and to what degree borrowers' choices might also be driven by inaccurate information about their future earnings. Several studies suggest that students are overly optimistic about their employment and earnings prospects, potentially leading them away from income driven repayment plans that act as insurance against low earnings or unemployment. Third, we ask what role information complexity plays in suboptimal decision-making. At present borrowers are faced with no fewer than seven repayment options, each with its own complicated set of rules. Moreover, the Department of Education and allied non-profit student loan servicers present borrowers with a potentially overwhelming amount of information on repayment plans. We ask whether this complexity paralyzes or confuses borrowers, potentially reinforcing the power of the default option.

To test these hypotheses we run an incentivized laboratory experiment using a facsimile of the federal government's Student Loan Exit Counseling web interface. The government's Student Loan Exit Counseling is required of all students with federal loans upon exiting schooling or falling below full-time status. It provides student borrowers with information about repayments and repayment options, and affords them an opportunity to select a repayment plan. Recreating this environment in the lab allows us to study the effect of varying parameters such as the default option and the way information is presented in a manner that will allow us to interpret results for the current policy environment.

We incentivize our experiment by telling subjects they will receive a draw from a distribution of what recent college graduates might expect to earn over each of the next 25 years, and that after subtracting necessary living expenses and any payments due on their student loans in each period, what is left over is converted according to an exchange rate to U.S. dollars, meaning they keep some fixed percentage of their net earnings. Subjects thus face a choice between a repayment plan that requires quick and possibly lower-cost repayment, and one that provides protection against default and allows for a longer repayment horizon, potentially at the cost of increased interest capitalization. Importantly, if in any period earnings net of living expenses are less than what they are required to repay on their student loan according to their repayment plan, they will go into default, which both reduces their future earnings in the experiment and triggers an additional fixed monetary penalty.

As in current Department of Education policy, the Standard plan is the pre-selected default option in our Baseline treatment. We then ask whether simply changing the default option can lead students to better choices of repayment plan. We choose the REPAYE plan (a revised version of Pay As You Earn) 
as our IDR policy alternative as it is the government's current and most highly publicized income driven repayment option, and hence the most policy-relevant candidate. In addition to changing the default from Standard to REPAYE, we also include treatments that give students straightforward information about the distribution of earnings of recent college graduates, treatment cells that present them with a pairwise choice between Standard and an income driven plan, and treatments that reduce the complexity of information found on the Exit Counseling site.

We find that the default option has a dominant effect on borrowers' choices. While nearly $60 \%$ of borrowers in the baseline treatment choose the Standard plan, near identical to the actual proportion among current borrowers, only 34\% choose it when the default option is an income driven plan. This suggests that the government has a very easy policy lever to pull if it wants to increase uptake of income driven repayment plans.

We contrast this with our second finding. Providing borrowers with clear and concise information about the distribution of earnings among recent college graduates has little effect on decision making. Nearly an identical share chooses the Standard plan whether or not we provide this earnings information. Similarly, we find little impact of reducing complexity and choices. When borrowers are presented with only a pairwise choice, between Standard and an income-based plan, and simple information as opposed to the complexity on the government site, they are equally likely to choose Standard as they are when they face the full amount of complexity. Further experimental treatments check for effects of changing the plan name (from "Standard" to "Fixed"), allowing students to ignore counseling before making a decision (a test of effects of impatience), or estimating effects by subject risk tolerance. None of these treatments elicit significant differences from the baseline treatment.

Taken together the evidence suggests that the default option plays an outsized role in borrowers' choice of repayment plan, driving them in many cases to suboptimal choices.

\section{Background}

The U.S. Department of Education (ED) is the largest originator of student loans in the country. The majority of loans are distributed to students through the Direct Loan Program, which makes both unsubsidized and subsidized loans, the latter to students with demonstrated financial need. ${ }^{2}$ Education provides the loans and maintains an informational website. The servicing of loans, including

\footnotetext{
${ }^{2}$ Interest does not accrue on the subsidized version while borrowers are in school, during a 6-month post-schooling grace period, and during periods of deferment (for continued schooling or economic hardship). Borrowers also have the option to consolidate Direct Loans; consolidation affects their terms and repayment.
} 
communicating with and counseling borrowers on plans and repayment options, is contracted out to four Title IV or six non-profit servicers.

Historically, take-up of income driven repayment plans (IDRs) has been low despite efforts by The Department of Education to promote them. These plans tie repayments to earnings, for the most part taking $15 \%$ of adjusted gross income above $150 \%$ of the poverty line with forgiveness after $20-25$ years. Most borrowers are eligible for these plans, in particular in the first years after exiting school, when earnings low. Hershbein et al., (2014) estimate that up to $99 \%$ of recent borrowers would have been eligible in their first year.

It is unclear why take-up is so low. A recent working paper by Abraham, et al. (2018) explores the importance of the framing of IDRs vs. fixed plans coupled with students' earnings expectations. The authors survey undergraduates at the University of Maryland and present respondents with scenarios in which they are assigned some level of borrowing and a set of choices between a fixed repayment plan and one that adjusts to income, with various framings. They find that students are more likely to choose a generic IDR plan when framing focuses on the insurance aspects of the plan, suggesting that the government's current framing, which emphasizes the potential for a longer repayment period and higher total payments, is in part acting as a deterrent. Moreover, they find that these framing effects are larger for students expecting a higher probability of low or no earnings after graduation but, conditional on this probability, expected earnings do not significantly interact with framing.

Borrowers' decisions about student loan repayments can have lasting consequences. There is currently no way to discharge student loan debt through bankruptcy. Any unpaid student debt is discharged only upon death or, in rare cases, permanent disability. ${ }^{3}$ Negative credit reports or low credit scores from late payments or default on student loans can reduce access to credit or increase its cost. Gaulke and Reynolds (2018) show that just entering delinquency on student loan repayments leads to nearly a 50 point hit to credit scores. ${ }^{4}$ It can also affect access to housing, and can reduce employment opportunities through employers' screening of credit histories. ${ }^{5}$ Research has shown the effect of student loan debt on everything from occupational choice (Rothstein and Rouse, 2011) and small business formation (Ambrose, et al., 2015) to home ownership (Mezza, et al., 2016).

\footnotetext{
${ }^{3}$ A recent paper by Yannelis (2017) suggests that reintroducing bankruptcy protection or eliminating wage garnishment would substantially increase default rates through "strategic" default by borrowers.

${ }^{4}$ Other recent papers attempt to directly estimate the effect of flags on credit histories, largely from bankruptcy, on liquidity and employment. Bos, et al. (2018) find that each additional year of negative credit information reduces employment by 3 percentage points and earnings by $\$ 1,000$ using data from Sweden. Herkenhoff et al. (2016) find that after credit flags are removed from histories, non-employed and self-employed individuals are more likely to move into UI covered employment at firms that pay higher wages. Another recent paper by Dobbie et al. (2016) finds that when bankruptcy flags are removed individuals have greater access to capital and borrow more, but they estimate only small and imprecise effects on labor market outcomes. ${ }_{5}^{5}$ A Society for Human Resource Management survey found that up to 60 percent of employers conducted background checks of at least some of their employees, usually for jobs involving financial responsibility. See also National Public Radio (2012) and New York Times (2013).
} 
The benefits of IDR's are not limited to protection against default. They also afford flexibility and lower the burden of repayments for those with low incomes, for whom payments can be a large percentage of take-home pay. Muller and Yannelis (2018) compare borrowers who were and were not eligible for IBR after its introduction in the wake of the Great Recession. They find that enrolling in an IDR plan reduced student loan defaults as well as the sensitivity of those defaults to home price fluctuations. ${ }^{67}$

Similarly, Herbst (2018) estimates the effect of enrolling in IDR on a variety of outcomes. The author's research relies on phone calls encouraging borrowers who are 10 or more days delinquent to sign up for an IDR plan. The author then makes pre-post comparisons between those who sign up for IDR and those who do not. He finds that IDR enrollees are less likely, by 21 percentage points, to fall 10 or more days delinquent four to seven months after the treatment. Enrollees also had higher credit scores and were more likely to hold a mortgage two years after. Similarly IDR enrollees also paid down more of their debt each month, despite lower required average payments, as a result of more timely and consistent repayment. From a variety of evidence, income-based repayment benefits both borrowers and lenders.

So why don't more borrowers choose IDRs? We next describe features of the student loan policy environment that we believe impact students' decisions and how we test for their significance in our experiment.

\subsection{The power of the default option}

There is ample evidence that the default option - the pre-selected option that individuals must take active steps to override - can have substantive impacts on important decisions. Johnson and Goldstein (2003) for example apply this to organ donation, showing that in European countries where citizens are required to opt into organ donation, participation rates are very low, while in countries where citizens must opt out rates are nearly $100 \%$. Similarly, Madrian and Shea (2001) demonstrate that workers in the same firm hired under opt-in vs. opt-out regimes for $401 \mathrm{k}$ retirement plans have dramatically different participation rates and investment choices. These and a variety of other studies suggest that individuals may take the default option as a recommendation, and that the informational and effort costs of switching can play a dominant role.

The student loan case fits this pattern precisely. First, students are pre-selected into the Standard 10 -year fixed repayment plan. Second, the name of the plan itself, "Standard," may suggest that this is the recommended option. Third, the cost of switching when not previously enrolled is high - borrowers must

\footnotetext{
${ }^{6}$ The study focused on Income Based Repayment (IBR), the leading plan at that time.

7 See Ionescu (2009) and Gary-Bobo and Trannoy (2015). for more theoretical work on student loan repayment schemes.
} 
contact their servicer, fill out a series of forms, and show proof that they are not able to make minimum payments in order to switch to an income-driven plan. A U.S. Government Accountability Office (2015) report addressing low IDR uptake notes that, while the Department of Education maintains information on IDR programs on its website, it has not established requirements for how servicers should communicate with borrowers about these plans. Their review of communications by servicers found "inconsistency" and lack of specificity in the information provided to borrowers about IDR plans. Borrowers were forced to seek out this information themselves, ostensibly from the government's student loan site (which we utilize in our experiment). The GAO concludes that in many cases borrowers are in fact unaware of these plans. Each of these factors can increase reliance on the default option, and they motivate our experiment.

\subsection{The relevance of information about earnings}

Standard human capital models of schooling often assume students have reasonably good, if not perfect, foresight into their future earnings. Thus, given perfect credit markets young adults can make optimizing decisions about college-going. Yet, empirical work (e.g. Betts, 1996) demonstrates that students' prior beliefs are not very accurate and that updating their beliefs with new information can have profound impacts on educational investments (including borrowing).

For example, Wiswal and Zafar (2015) show that students revise their beliefs about future earnings when shown the population distribution they can expect to face. They conclude that there is a strong role for "information campaigns" focused on providing students with accurate information. Current student loan exit counseling does not provide borrowers with information as to what recent graduates might expect to earn. If borrowers are over confident, they may be less likely to take IDR plans that offer insurance against low earnings.

To test this hypothesis, we include treatment cells where students are presented with simple graphical and text information presenting what recent college graduates earn in their first few years after college, including the share that earn less than what it would take to make the minimum payment on a $\$ 23,000$ loan under the 10-year fixed repayment plan, which is what subjects will face in the experiment.

\subsection{The role of complexity}

While classical economics suggests that having more feasible options is better, the behavioral literature suggests that increasing the number of choices and complexity of the decision environment can lead to sub-optimal decision making, often referred to as "choice overload" or "comparison friction". Behavioral economists and psychologists find that as the number of choice options increases (overload) and the availability of information becomes more difficult to access (friction) reliance on the default option 
increases. ${ }^{8}$ We expect this mechanism may be at work as students choose among loan repayment options. There are multiple options to choose from, including: Standard, Graduated, Extended, GraduatedExtended, Income Based Repayment (IBR), Income Contingent Repayment (ICR), Pay as You Earn (PAYE) and Revised Pay As You Earn (REPAYE) plans.

Further, the precise details of each program, including eligibility, are difficult to access and comprehend. Students are making these decisions with a great deal of uncertainty about how interest compounds, the insurance nature of the offer, eligibility for each program, and about their future earnings. In fact, some evidence suggests that students have a poor grasp of the extent of their own borrowing (Akers and Chingos, 2014). We ask whether this type of complexity is reinforcing the default option by including treatments where subjects are presented with only two choices (REPAYE and Standard) and are given a more straightforward description of each plan, its costs, and its benefits. ${ }^{9}$

\section{The Experimental Environment}

\subsection{Student Loan Counseling}

For our experiment we create a facsimile of the federal student loan Exit Counseling site, which all students with federal loans are required to use upon exiting school. ${ }^{10}$ This site allows borrowers to look up their current loans and choose a repayment plan as well as obtain information about repayment plans, how interest accrues, the nature of deferment, forbearance, delinquency and default, and tips for repaying.

The government site, StudentLoans.gov, ${ }^{11}$ consists of multiple pages that are clicked through sequentially. First, borrowers log in by entering their Federal Student Aid identification number to look up their existing loans or enter their loan information manually. Subjects using our experimental site have a loan amount and interest rate pre-entered for them. Once this information is populated, borrowers using the government site or subjects using our laboratory facsimile click through the site's pages. The first page ("Understand Your Loans") presents information on loan basics, including loan types, and allows students to click on information describing key concepts such as interest accrual, capitalization, promissory notes and acceleration. The second page ("Plan To Repay") allows borrowers to enter their projected annual income, to select any withholding and to enter other monthly expenses such as rent,

\footnotetext{
${ }^{8}$ Cronqvist and Thaler (2004) show this with respect to Social Security options in Sweden,. King, et al. (2012) report implications of choice friction in a field experiment on choice of Medicare Part D prescription drug plans in the U.S.

${ }^{9}$ We choose REPAYE as our alternative default option as it is the government's most recent IDR plan and the most likely candidate for an IDR default option.

${ }^{10}$ We make only minor changes to the site for the experiment: we do not allow subjects to enter personal information such as social security numbers and we and pre-fill their state of residence as Georgia.

${ }^{11}$ The URL for the site is https://studentloans.gov/myDirectLoan/exitCounseling.action?execution=e1s1.
} 
utilities and entertainment, amongst others. We pre-select our subjects to have a family size of one and to live in Georgia (for purposes of calculating income tax). We enter monthly expenses to be $150 \%$ of the federal poverty line; the purpose of this is to match what we deduct from their gross earnings in our experiment as living expenses, which we tell them up front. ${ }^{12}$

Once projected earnings are entered, repayment plans appear along with descriptions and radio buttons to make a selection. In Appendix A2 we show a screen shot of this portion of the page with the loan parameters we use in the experiment (a \$23,000 Direct loan) and enter \$24,000 in expected earnings in the next year to provide an example for the reader. ${ }^{13,14}$ It is here where borrowers or subjects can choose a repayment option by clicking on the radio button of the plan they want. If no action is taken, they remain in the pre-selected default plan. At the bottom of page two there is a host of additional information including repayment incentives and tips on navigating repayment. ${ }^{15}$ Pages three through five present no new choices, but do provide additional, possibly overwhelming, information on avoiding default (page three, “Avoid Default”), making finances a priority (page four, "Finances: A Priority"), and finally a summary page (page five, "Repayment Information") where they can enter contact information to facilitate contact with their servicer. In the experimental facsimile, we replace page five with a summary page of their decisions (and we do not allow them to enter personal information such as a driver's license number, address, or phone number).

\subsection{Incentivizing the experiment}

We set up the experiment by telling subjects that they have a Direct Subsidized federal student loan of $\$ 23,000$ at $4.6 \%$ interest - the maximum subsidized student loan amount at the time - and pre-entering this information for them. ${ }^{16}$ In our instructions we describe the parameters of the experiment. Subjects are told that they will be asked to go through student loan exit counseling and can choose a repayment plan. They are also told that they will be compensated for the experiment by receiving a random draw "from the distribution of what actual recent college graduates with a Bachelor's degree might expect to earn over each of the next 25 years."

\footnotetext{
${ }^{12}$ In the experiment all earnings, repayments and poverty calculations are based on a single individual to abstract from dual income and dual loan issues within households.

${ }^{13}$ Borrowers and subjects can enter as many earnings values as they like. In the case shown in the Appendix and which is relevant to our experiment, borrowers with loans below $\$ 30,000$ are not eligible for Extended repayment plans.

${ }^{14}$ The government's web page extrapolates earnings at a 5\% growth rate, which borrowers cannot change on ours or the government's site. The GAO has questioned this calculation and suggests that ED modify it to be more realistic.

${ }_{15}$ Note that some changes in details have taken place on StudentLoans.gov since our 2017 experiment and visiting the site now may present somewhat different information. We have preserved and provide links to our experimental facsimile. To see exactly what our subjects were presented with, go to https://excen.gsu.edu/jccox/instructions.

${ }^{16}$ This information is pre-entered for them on our facsimile of the student loan exit counseling website where they would normally enter their Federal Student Aid identification number which would fill in the form with their loan information.
} 
The incentive structure in the experiment revolves around the trade-off between repaying quickly, the risk of loan default, and the costs associated with defaulting. We take two steps to make these features salient in our experiment. First, we tell subjects that at the end of each period we subtract from their gross earnings federal payroll tax (FICA), and from the remainder of their earnings we subtract $150 \%$ of the federal poverty line to represent necessary living expenses. This benchmark corresponds with the earnings level at which students in income driven repayment plans are no longer required make loan payments.

Second, we tell subjects that from their earnings net of tax and living expenses, we will subtract any payments due on student loans. We inform them that if in any period their net earnings are less than what they are required to repay on their student loan, they will go into default and incur a penalty (they are afforded one period of forbearance, so default is not immediate).

For the penalty, we impose a two-fold cost of default. First, we decrease future earnings by 10 percent (which reduces their expected payout from the experiment). Second, at the beginning of the experiment we endow subjects with an $\$ 8$ "gift". ${ }^{17}$ If they default at any point, they forfeit this 8 dollars. These penalties are meant to make the cost of default salient to participants. They are also structured to replicate the fact that defaulting on a student loan has a significant impact on credit scores, potentially increasing the cost of future borrowing, and possibly hurting future employment opportunities. The full set of instructions provided to subjects is shown in Appendix A1. ${ }^{18}$

Loan payments in each period depend on the repayment plan subjects select. If a subject chooses a fixed repayment plan, for example the Standard plan, she faces an inflexible payment due each period. If she chooses an income driven plan, payments are a deterministic function of earnings, and she cannot default. Hence, by choosing one of the income driven repayment plans, subjects can completely inoculate themselves against default.

To generate earnings we use data from the 2012-13 (3-year) American Community Survey (ACS). We limit the sample to 461,802 individuals ages $24-49$ with a four-year bachelor's degree. We estimate a pooled regression of earnings on a quartic in years since age 24 . We use coefficients from this regression to create an empirical age-earnings profile which we then collapse into 20 representative ventiles. Deducting FICA (7.65\% of earned income) gives us Adjusted Gross Income (AGI). We then calculate "discretionary income" as the difference between AGI and 150\% of the one-person household poverty level, which is $\$ 17,505$.

In Figure 1 we plot expected earnings from alternative repayment plans compared with the Standard repayment plan by ventile of the earnings distribution where the only penalty to default is a $10 \%$

\footnotetext{
${ }^{17}$ This 8 U.S. dollar endowment is separate from the 5 U.S. dollar show-up fee subjects receive that they cannot lose.

${ }^{18}$ Subjects could read the instructions on their computers and were given a paper copy to reference throughout the experiment.
} 
reduction in future earnings as calculated from ACS data. The figure demonstrates that the income adjusting plans are dominant at the low end of the earnings distribution: $35 \%$ of 24 -year-olds have annual earnings below $150 \%$ of the poverty line and thus default with the Standard plan under our conditions.

Strikingly, the largest gap we see between the Standard plan and the income driven plans is for the few borrowers just below the median of the distribution where borrowers earn about $\$ 10,000$ more in expectation from choosing Standard as opposed to REPAYE. Table 1 shows these differences in expectation over the entire earnings distribution assuming only a $10 \%$ reduction in earnings following default and not including the $\$ 8$ fixed penalty. Not only do we show that borrowers under our scenario can expect to gain about $\$ 14,500$ by choosing REPAYE (or PAYE) over the Standard plan but, importantly, the variance is far lower as well. Column 2 shows the difference in the standard deviation of net earnings compared to the Standard plan. Not surprisingly, earnings variance is lower for IDR plans as default is not in play. The purpose of this exercise is to demonstrate that under reasonable assumptions, there are very few scenarios under which being tied to a fixed repayment plan is optimal, particularly if we assume borrowers are risk averse.

The realization of this simple parameterization of earnings and repayment reveals a salient feature of the current set of repayment options offered by the federal government for Direct student loans - that there is an ex ante dominant choice. In fact, we don't even need these simulations to demonstrate this. One of the government's older plans (PAYE) stipulates that students are required to pay the minimum of $10 \%$ of earnings above $150 \%$ of the poverty line or whatever their payment would be under the Standard plan. In other words, PAYE offers the insurance protection against low earnings without adding a requirement to repay quickly for high earners whilst maintaining the option to prepay to avoid interest capitalization. The government, possibly realizing that this plan could be expensive, revised it with REPAYE, which removes the Standard plan repayment cap and also removes a maximum earnings qualification condition. We focus on this updated version here as it is the newest and most policy relevant option.

We convert subjects' simulated lab earnings into U.S. dollars at a rate of $\$ 2.50$ for every 100,000 they earn in the lab. Figure 2 shows U.S. dollar payout differences compared with the Standard repayment plan for all 20 ventiles of the lab earnings distribution, including the 8 U.S. dollar penalty subjects pay if they default. It is important to keep in mind that only subjects in treatment arms that give information about earnings of recent graduates at age 24 have some, but not full, information about the earnings distribution. 


\subsection{Main Treatment Cells}

Table 2 lists the 14 treatment cells in our experiment. All of the treatments can be found in full at https://excen.gsu.edu/jccox/instructions. The first 8 are our "main" treatments, which vary the three key parameters discussed above (the default option; information about earnings; complexity). In treatments 14 we retain the full amount of complexity and choices borrowers face outside of the lab and either change only the default option to REPAYE (treatment 2), add only information about earnings (treatment 3 ), or change both (treatment 4$)$.

We define treatment 1 as the "Baseline" treatment which presents the Exit Counseling web interface as borrowers experience it on the government site - Standard is the pre-selected default option, no information about earnings is provided, and they face the full complexity of information and choices. In treatments where REPAYE is the default, we pre-select REPAYE as opposed to Standard and re-order options such that REPAYE appears first (where Standard was) and Standard is then moved to the spot where REPAYE was.

In order to provide subjects with information about earnings we use data from the ACS and calculate deciles of the empirical earnings distribution of recent graduates at age 24 as of 2015 . To make information easily understandable to subjects, we present them with bullet points describing what typical college graduates with a Bachelor's degree earn at that age. One of these bullet points indicates the share that earned less than $150 \%$ of the poverty line. Below this information we provide a simple table that displays deciles of the earnings distribution along with annual and monthly total and discretionary income. Lastly, we provide three bullet points relating discretionary income to total income and repayments. This information, displayed in Appendix A3, was designed to fit the formatting of the government site. Subjects are shown this information on the second page of Exit Counseling, just above where they make their repayment decision.

We then repeat this $2 \times 2$ treatment matrix under simplified information in treatments 5-8, shown in Table 2. Where our "Complex" treatments described above reflect what is actually on the student loan exit interview, in our "Simple" treatments we limit to a pairwise choice between Standard and REPAYE and provide only one page with a straightforward description of each plan. Appendix A4 shows a screen shot of the decision page (page 2) for "Simple" treatments. Under simplified information, subjects are not presented with all 5 web pages to click through, but are rather only given a pairwise set of choices and one page of information to navigate.

\subsection{Additional treatment cells}

In addition to our main treatments, we test two additional hypotheses. The first is to address the fact that in our experiment we direct subjects to Exit Counseling. In reality, although it is required by law, students 
can skip counseling. We know of no statistics reporting the share completing counseling. If many borrowers skip, then providing information about earnings or simplifying the information they see will only affect those who choose to go to the site. On the other hand, if many borrowers skip, the effect of the default option would be even stronger than we find here - if borrowers skip exit counseling they are automatically defaulted into Standard outside of the lab.

To test for this we modify four of our main treatment cells to allow subjects to skip the decision making part of the experiment and promptly leave the lab to receive their payment under the default repayment plan in the treatment (which is Standard or REPAYE depending on the treatment). ${ }^{19}$ Comparison of data from otherwise identical treatments allows us to ask whether impatience and inattention significantly promotes adoption of the default repayment plan. To execute this we include at the end of our instructions language describing the option to exit the interview at any time, noting that subjects will then be assigned a "pre-selected repayment plan" to pay off their loans if they do so. In addition, we include a "Skip Exit Counseling" button on the menu of each page of the interface which is meant to replicate borrowers' ability outside the lab to exit counseling by simply closing their browser (perhaps because they become confused, overwhelmed, impatient, or frustrated). These treatments also allow us to observe when in the interview subjects exit; for example to see if they make it to the choice page, and the share of subjects who choose to do so. Similarly, we can observe if subjects who persist are a select group by observing whether effects of changing the default, reducing complexity or providing earnings information are different from those who are not authorized to exit without sacrificing salient rewards.

A second alternate hypothesis we test is the effects of plan names. One might expect that the name itself, "Standard", would imply a suggestion. It is not difficult to interpret "Standard" as "what everyone else does" or what one "should" do. Overwhelmed or confused borrowers might not want to choose a "non-standard" plan. To test this, Treatments 13 and 14 differ, respectively, from treatments 1 (baseline) and 3 (REPAYE + earnings information) only by changing the name of the Standard repayment plan to "Fixed."

The experiment is computerized and run in the laboratory of Georgia State's Experimental Economics Center (ExCEN). Subjects are recruited through the lab's online recruitment facility using a filter which limits participation to undergraduates beyond their freshman year who are U.S. citizens. These restrictions were put in place to focus on subjects who persist through their first year of college, when dropout is highest, and to focus on those eligible for federal student loans. We recruited 542

\footnotetext{
${ }^{19}$ Subjects in these treatments are allowed to leave the lab and collect repayment in a separate room as soon as they are finished.
} 
subjects to participate in 15 sessions over the spring and fall of 2017 (the fall sessions were conducted for our additional treatment cells, T9 - T14). At the end of a session we collect subjects' demographic information and conduct an incentivized risk elicitation task (Eckel and Grossman, 2002; 2008). The characteristics of subjects who participated in the experiment are reported in Table 3 . They are $38 \%$ male, $61 \%$ black, with average age 20.6 years. Of these, $49 \%$ are arts and sciences majors and $27 \%$ business majors; $73 \%$ of our subjects reported having student loans.

\section{Results}

\subsection{Benchmarking our Baseline treatment}

We begin by benchmarking our Baseline specification to the distribution of repayment choices at the national level. This is relevant to demonstrating that choices and incentives faced by subjects in the lab parallel those faced by student borrowers outside of the lab. The rightmost column in Table 4 shows results from the distribution of repayments as reported by two recent GAO reports and the distribution of repayment choices selected by our subjects in the Baseline specification. ${ }^{20}$

The earlier (2015) GAO report, using data from the National Student Loan Data System (NLSDS) for borrowers with outstanding loan balances as of September 2014, finds $65 \%$ of borrowers in the Standard plan, $14 \%$ in Graduated, and $19 \%$ in one of the income driven repayment plans. A similar (2016) study from the GAO shows that 24\% of borrowers in Q3 of 2013 through Q3 of 2016 were in an IDR plan with the remaining $76 \%$ in the Standard or Graduated (fixed) repayment plans.

The right-most column of Table 4 shows results from our Baseline treatment in which $62.5 \%$ of our subjects chose the Standard plan, $12.5 \%$ chose Graduated, and 25\% chose one of the IDR plans. If we take the more recent (2016) GAO report in column 1 and compare with our Baseline results in column 3, we find that $76 \%$ of our subjects chose a fixed repayment plan (Standard or Graduated) compared with $76 \%$ of actual borrowers, and that $25 \%$ of our subjects chose an IDR plan while $24 \%$ of national borrowers are in one of these plans. Comparing our results with the 2015 GAO report shows that we are within 1 percentage point of the share choosing Graduated repayment, and that our subjects were only 2 percentage points less likely to choose the Standard plan, and had a marginally higher likelihood of choosing IDR plans, by 6 percentage points, than actual borrowers.

We believe that these figures suggest not only that our experiment reflects to some degree the data generating process in actual repayment choices, lending credibility to the counterfactual policy 
simulations we run, but also that our subjects are taking the experiment seriously and are not choosing blindly (any more than they are outside of the lab).

\subsection{The default option and information about earnings}

Table 5 shows uptake rates across treatment cells in the complex environment. We collapse subjects' repayment choices into four categories: Standard, REPAYE, Graduated and Other IDR plan. Effectively this collapses the least utilized and older income driven plans (PAYE, ICR and IBR for New Borrowers) in to Other IDR. The reason for this is that few subjects (or borrowers) choose these plans and for our purposes they can be considered a single outcome - one that implies leaving the default and choosing an IDR plan other than REPAYE.

The Baseline treatment distribution is shown in row 1 of Table 5 where 62.5 percent of subjects chose the Standard plan and only 7.5 percent chose REPAYE. The following three rows show the choice distribution from changing the default option, from presenting earnings information, or from the combination of the two. Raw means in Table 5 suggest that while providing borrowers with earnings information has little impact, simply changing the default option results in a 28 percentage point (45\%) decrease in the share choosing Standard and a 24 percentage point, or four-fold, increase in the share choosing REPAYE. The effect of changing the default option coupled with earnings information shows an even larger impact.

To facilitate interpretation and statistical tests given multiple potential outcomes, in Table 6 we show results from a multinomial logistic regression and present transformed marginal effects. The purpose of the regression is to observe changes in the observed choice distribution, as opposed to merely the effect of switching to REPAYE on choosing Standard, though this statistic is covered as well. We estimate this as follows:

$$
\begin{aligned}
& \ln \left(\frac{P(\text { REPAYE })}{P(\text { Standard })}\right)=\beta_{01}+\beta_{11} \text { DEFAULT }+\beta_{21} I N F O+\beta_{31}(\text { DEFAULT \& INFO })+\varepsilon_{1} \\
& \ln \left(\frac{P(\text { Graduated })}{P(\text { Standard })}\right)=\beta_{02}+\beta_{12} \text { DEFAULT }+\beta_{22} I N F O+\beta_{32}(D E F A U L T \& I N F O)+\varepsilon_{2} \\
& \ln \left(\frac{P(\text { therIDR })}{P(\text { Standard })}\right)=\beta_{03}+\beta_{13} \text { DEFAULT }+\beta_{23} I N F O+\beta_{33}(D E F A U L T \& I N F O)+\varepsilon_{3}
\end{aligned}
$$

where the transformed $\beta$ 's show the marginal effect of each treatment on the probability of choosing each outcome relative to the Baseline. Note that the three treatments are modeled here as mutually exclusive for ease of interpretation, thus the effect of both changing the default option and giving earnings 
information (treatment 4) is not the sum of the three coefficients but rather is simply the set of coefficients in the third column, $\beta_{3-}$.

We complement these estimates with specification checks in Panel B that add session fixed effects, school-within-the-college fixed effects, and a set of subject demographics including age, year in college, gender, race, whether the subject reported having loans, and a measure of risk tolerance. We find that these have no discernable impact on estimates (an F-test fails to reject the null that all are jointly significant).

The table columns index each treatment relative to the Baseline, and the rows indicate the marginal effect of these treatments on the likelihood of choosing each outcome. Thus, column 1 demonstrates that switching the default option to REPAYE results in a 27 percentage point increase in selecting REPAYE relative to the Baseline, and a 26 percentage point decrease in Standard.

Column 2 of Table 6 shows the effect of providing information about the distribution of earnings of recent graduates (treatment 3). Compared with the Baseline, we find that this has no discernable effect on choosing Standard and results in a slight increase in choosing REPAYE, though this result is imprecise. These limited effects are not simply the result of subjects ignoring the information we provide. As evidence, Figure 3 shows subjects' responses to survey questions asking what they expect to earn in their first year after graduating, and what the average undergraduate might expect to earn. Not surprisingly, on average subjects believe they will earn more than the typical undergraduate, and overestimate how much a typical undergraduate earns. Subjects not exposed to treatments that provide earnings information say they expect to earn nearly $\$ 50,000$ after graduation, and expect the typical undergraduate to earn about $\$ 37,000$. Yet, those in treatments that included information about earnings reported they expect to earn $\$ 8,500$ (17\%) less themselves and expect their peers to earn $\$ 5,200(14 \%)$ less. Despite this updating, providing information does not dissuade them from the Standard plan on average.

In the final column of Table 6 we show the effect of both changing the default option and providing information about earnings. The effect of both treatments compared with the Baseline is an increase in both REPAYE and Graduated, and a large decrease in the probability of choosing Standard, though only the last of these is statistically different from estimates of just changing the default to REPAYE shown in column 1. This suggests that the effect of earnings information on choices might depend on the framing subjects face. When subjects are defaulted into the Standard plan, where income is not a factor in required repayments, information about earnings is not salient. Yet, when subjects begin with REPAYE as the default setting, they are confronted with income-contingent repayment that forces attention on earnings, increasing salience. 
Our conclusions from the first set of estimates are three-fold. First, we find that the default option plays a strong role; switching the default from the Standard plan to REPAYE reduces the share who select the Standard plan by nearly half and increases the share who choose REPAYE by roughly a factor of four. Second, we find that misguided beliefs about earnings cannot explain subjects' choice of the Standard plan. Third, we find that combining earnings information with switching the default led to better decisionmaking than changing the default alone.

\subsection{Reducing complexity}

We next consider treatments where we limit the number of choice options and the amount and complexity of information borrowers face when considering repayment options and ask whether this affects decisionmaking. This has the advantage of isolating the decision between fixed (Standard) and flexible (REPAYE) repayment options, similar to Abraham, et al. (2018), but comes at the cost of limited information to subjects and a loss of straightforward policy implications - while reducing or reorganizing the amount of information borrowers face is a realistic option, presenting them with only two choices may not be. The purpose here is to observe whether information complexity is reinforcing the effects of the default option on choice of the Standard plan.

The first two columns of Table 7 show the distribution of repayment choices across our simplified environment. In the Simple Baseline treatment (Standard is the default and no earnings information is provided), 58 percent of subjects stayed in the Standard plan while the remaining 42 percent switched to REPAYE. This 58 percent is close to the 62 percent we observe in the Baseline treatment with the complex environment in Table 5.

Of course, we cannot easily compare across treatment cells in simple and complex environments as subjects are not presented with the same set or number of choices across treatments. If we assume subjects who chose Other IDR when all options were available would also prefer REPAYE over Graduated or Standard, we might expect that they would all move toward REPAYE when choices are limited to just that option and Standard. In Table 5 we saw that 25 percent chose one of the IDR options, including REPAYE, when all options were available. In the simple framework, when just the two options are available, we observe 42 percent choosing REPAYE. Thus it appears that the simple environment, with limited choices and information, may have increased the proportion of subjects' choices from a fixed to an IDR option by about 17 percentage points, though this is an upper bound estimate according to our assumptions.

Within treatments for the simple environment (reported in Table 7), we find that switching the default option has no impact on the share of subjects who choose the Standard plan. In fact, an equal share of subjects switch back to the Standard plan when placed in REPAYE as the default. This provides 
some evidence that pairwise comparisons to isolate preferences for repayment types in the lab are not directly transferable to policy scenarios where individuals face more complex information.

Similarly, additional information about the distribution of earnings by itself has no impact on choices either, even though this information, theoretically, should be more salient in the simple treatment world where less information overall is present. Yet, similar to comparisons of the Baseline treatment in the complex environment, a combination of switching the default and giving earnings information decreases uptake of the Standard plan, here by somewhat less than half.

The final two columns of Table 7 show coefficients from a linear regression with choosing Standard as the dependent variable with (column 3) and without (column 4) subject covariates included. Results confirm what we see in raw means - no effect from changing only the default or adding only information, but changing both has a meaningful impact, decreasing the likelihood of choosing Standard by roughly 31 percentage points, equal to about 50 percent. This result, an interaction effect between changing the default and providing earnings information, where we observe no effect of either treatment by itself, suggests that the impact of new information, for example about earnings, may become more salient once individuals are pried from the default option as we saw in the complex setting as well.

\subsection{Risk and decision making}

We thus far have found little evidence of gains from simply providing borrowers with information about earnings. However, we expect that any effect of information might depend on subjects' taste for risk. If (on average) borrowers overestimate future earnings, then informing them that they are at higher risk for default than their priors suggest should have strongest effects for those who most dislike risk.

To examine this, we take four key treatment cells and interact each with a linear risk preference measure. Our risk measure is taken from an Eckel-Grossman $(2002,2008)$ risk attitude elicitation task where subjects are given 6 sets of paired lottery choices (coin flips) to choose between that vary in expected payoff and risk, where subjects choosing option 6 have the highest risk tolerance in our case. ${ }^{21}$ The task is incentivized with subjects earning between $\$ 0.20$ and $\$ 7.00$ depending on the riskiness of their gamble and the outcome of their coin flip.

Table 8 shows results from this regression. In columns 1-3 the dependent variable is a binary indicator of choosing any IDR plan, including REPAYE. Columns 4-6 repeat the exercise using a binary indicator for Standard as the dependent variable. In all cases we center the risk attitude measure at its mean value of 3.7 (the median and modal value is 3 with a s.d. of 2.2). We find little relationship between

\footnotetext{
21 Our risk elicitation task is taken, along with our demographics questionnaire, after subjects complete the experiment. In a check we find that controlling for their earnings draw, to account for possible wealth effects on elicited risk preferences, has no effect.
} 
risk attitude and choices in the Baseline, observed in the main effect on the coefficient for Risk. Yet, we find that providing information about earnings pushes subjects with a higher risk tolerance toward IDR plans and away from Standard. This is inconsistent with a story where updated information about earnings has a larger effect on more risk-averse subjects, but is consistent with a world in which less riskaverse individuals are more likely to overestimate future earnings. We find some evidence of this. A regression of expected earnings on risk attitude shows a positive though very noisy relationship between risk and expected earnings, suggesting a \$1,000 increase in expected own-earnings associated with a one unit increase in our risk measure.

\subsection{Alternative hypotheses: testing for effects of shirking and implicit endorsements}

In our final set of treatments we test two potential alternative explanations for widespread use of the Standard plan. One explanation is that borrowers shirk their responsibility for making an informed choice of repayment plan by skipping counseling entirely. Another is that borrowers interpret the name "Standard" as an implicit endorsement of this plan.

We begin with shirking. In our main treatment cells we show effects for subjects who were required to make a decision in order to collect salient payoffs from the experiment. ${ }^{22}$ But, student loan policy cannot prevent shirking. Although exit counseling is "required" for all borrowers by the U.S. Department of Education, we are unaware of any enforcement mechanism.

In our first alternative treatment we tell subjects they can leave whenever they choose after hearing instructions and descriptions of payoffs, and allow them to skip exit counseling entirely but still collect rewards from the experiment. The analog of this in the national student loan program is borrowers who never bother to complete exit counseling, or who begin counseling but quit before finishing. We implement this in the lab by including in our instructions that subjects have the option to participate in exit counseling and that at any time they can skip exit counseling, in which case they will be assigned to "a preselected repayment plan" to pay off their loan. They are also told that they may leave the lab without completing the experiment tasks and still receive full payment including salient rewards. The purpose of this treatment is to gain insight into what degree being defaulted into the Standard plan outside of the lab is driven by subjects never completing counseling or taking other active steps to learn about their repayment options. We cross this treatment with four of our main treatments: Baseline, and REPAYE Default + Earnings Information, across both the simple and complex information settings.

\footnotetext{
${ }^{22}$ In compliance with standard IRB policy, subjects could leave the lab at any time and receive their $\$ 5$ participation (or showup) payment. In the main treatment cells, however, subjects must complete the decision-making part of the experiment in order in order to also receive salient payoffs from choosing a repayment plan.
} 
Of the 155 subjects in these treatment cells, 20 percent skip the exit interview (see Table 9). Among skippers, nearly all skipped on or before the decision page (page 2 of counseling) in which they see all of the choices. We find that subjects were less likely to skip when presented with less information, suggesting unsurprisingly a degree of impatience among college students. By construction, those who skip are defaulted into the default plan according to their treatment cell, hence allowing for inattention and increasing the switching cost naturally reinforces the power of the default.

A more interesting question is, do those who do not skip counseling behave differently than skippers? We find little evidence that they do. Table 10 compares outcomes when subjects are and are not given the opportunity to skip Exit Counseling. We find that either in the simple or complex information setting, when we compare those who did not skip with those who were not offered the option to skip, the distribution of repayment choices looks quite similar (we cannot reject the null that proportions are the same in nearly all cases). For example, in the true Baseline treatment, 63 percent remained in Standard. When we allow subjects to skip, 74 percent remain in Standard. Of those who were given an opportunity to skip but did not, 65 percent remained in the Standard plan, statistically no different than the 63 percent who chose standard when they were required to finish the experiment to collect salient payoffs. We find some evidence of a shift toward REPAYE among non-skippers in the Baseline, at the expense of Graduated, but hypothesis testing fails to reject that the effect is zero.

In a final test we ask if the name itself, "Standard", may suggest to borrowers that this is the recommended plan. In two final treatment cells we vary the name of the default option from "Standard" to a less connotative "Fixed". We do this for the Baseline and for REPAYE Default + Earnings Information (treatments 13 and 14). Results in Table 11 show no statistical difference (from a chi-squared test) in the distribution of repayment options suggesting that the name does not play a strong role in choices.

\section{Conclusions and Policy Implications}

Our experiment is motivated by the fact that many borrowers default on their student loans despite options that provide protection against default though income driven repayment. In fact, many borrowers pass up a plan that provides insurance against low earnings without requiring a sacrifice in consumption if earnings are high.

While standard models of economic behavior fail to explain this pattern, we find that behavioral economics does. In our incentivized laboratory experiment we find that the default option plays an outsized role in subjects' choice of repayment plan, and that simply changing which plan is pre-selected reduces the share of subjects choosing the Standard plan, the plan of "choice" among the majority of loan repayment defaulters, by nearly half. 
In contrast, we find that while simply providing borrowers information about the distribution of earnings they might expect leads them to update their beliefs about their own and others' future earnings, it has little effect on their choice of repayment plan. Yet, when we provide this information and change the default option to an income driven plan, behavior does change. This suggests that earnings information becomes salient when choice of income-invariant repayment plan requires a decision to actively switch plans.

We consider other mechanisms as well. In particular, we test how information complexity affects behavior and ask what happens if we limit the number of choices and amount of information subjects face. We find that reducing complexity does not dissuade subjects from the Standard plan. Our results support the conclusion that the default option plays a stronger role than any of these other features of the student loan policy environment, although they suggest an effect from adding earnings information with change in the default, either in the complex or simple environment.

Our results speak to three strands of research. First, we reinforce prior work demonstrating that the default option influences choice and that a poor selection of that option can lead to suboptimal and even detrimental outcomes (Samuelson and Zeckhauser, 1988; Madrian and Shea, 2001; Johnson and Goldstein, 2003; Thaler and Sunstein, 2003; de Haan and Linde, 2018).

Second, we build on the literature addressing the causes (Abraham, et al., 2018; Looney and Yannelis, 2015) and consequences (Baum, 2015; Bleemer, et al. 2014; Field, 2009) of student loan defaults. In particular, through an experimental survey Abraham, et al., (2018) find that simply reframing a generic IDR type repayment such that the insurance protection of the plan is emphasized over the increased cost leads to increased take up. This fits as well within a related literature on informational nudges targeting student borrowers at college entrance (Marx and Turner, 2018; Castleman and Page, 2016; Barr, Bird and Castleman, 2017).

Third, and in the broadest sense, we contribute to a discussion on returns to higher education. There is no shortage of public opinion that we are in the midst of a student loan "crisis." Yet, returns to college remain large and increasing. Dynarski and Kreisman (2013) speak directly to this apparent contradiction in the inability of many college graduates to repay loans, despite increasing long run returns to schooling. Part of this is simply due to high variability in earnings in early careers, even for college graduates; and part of it is due to the fact that returns to schooling accrue over a lifetime, not immediately after graduation. Hence, offering flexible repayment plans that vary with earnings makes sense, both for borrowers and lenders. The problem then is not that these programs are not offered, but rather that that are not utilized.

If the federal government's rational for defaulting students into the Standard plan is that borrowers will make optimizing decisions, we believe our results, in addition to statistics about 
repayment choice and default among U.S. borrowers, suggest that this belief is misguided. For example, having been offered the opportunity to choose an ex ante optimal plan, one would expect borrowers to choose it in large if not overwhelming numbers. One would also expect to see borrowers with low earnings, putting them in jeopardy of default, shift toward income driven repayment plans. There is little evidence of either behavior in national student loan data.

Importantly, in our case, if borrowers (or subjects) are behaving optimally and with full information, then changing the default option should have little effect. We find the opposite. Given these facts, it appears that there is little justification for making Standard the default plan. Findeisen and Sachs (2016) show not only that income driven loan contracts are optimal from a public investment standpoint, but also that these results can hold under a straightforward repayment schedule. Lochner and MongeNaranjo (2016) make similar claims. Mueller and Yannelis (2018) demonstrate that this type of repayment scheme is effective in providing protection from negative shocks. Herbst (2018) shows that despite lower required contributions on average, IDR enrollees pay down more of their debt as a result of more timely and consistent repayment.

From a policy perspective, this need not be controversial. Australia and New Zealand have implemented fully income contingent repayment strategies. The UK, Canada and South Africa feature them prominently. Legislative efforts in the U.S. to shift to an income based repayment scheme have gained little traction. Past efforts to nudge borrowers into income driven plans has seen limited success. But none of these reform policies has shifted the default option. 


\section{References}

Abraham, K., Ozbay, E.F., Ozbay, E., and Turner, L. (2018). "Framing Effects, Earnings Expectations, and the Design of Student Loan Repayment Schemes." Working Paper.

Akers, Beth, and Matthew M. Chingos. "Is a student loan crisis on the horizon." Brown Center on Education Policy, Brookings Institution (2014).

Ambrose, B. W., Cordell, L., \& Ma, S. (2015). The impact of student loan debt on small business formation. Federal Reserve Bank of Philadelphia Working Paper No. 15-26.

Ballance, J., Clifford, R., \& Shoag, D. (2016). "No More Credit Score”: Employer Credit Check Bans and Signal Substitution,". Working Paper.

Barr, A., Bird, K., \& Castleman, B. L. (2016). Prompting active choice among high-risk borrowers: Evidence from a student loan counseling experiment. EdPolicyWorks Working Paper.

Baum, S. (2015). Does Increasing Reliance on Student Debt Explain Declines in Entrepreneurial Activity? Posing the Question, Gathering Evidence, Considering Policy Options. Research Report. Urban Institute.

Bettinger, E. P., Long, B. T., Oreopoulos, P., and Sanbonmatsu, L. (2009). The role of simplification and information in college decisions: Results from the H\&R block FAFSA experiment. Technical report, National Bureau of Economic Research.

Betts, J. R. (1996). What do students know about wages? Evidence from a survey of undergraduates, Journal of Human Resources, vol. 31, issue 1, 27-56.

Bleemer, Z., Brown, M., Lee, D., \& Van der Klaauw, W. (2014). Debt, Jobs, or Housing: What's Keeping Millennials at Home?, Federal Reserve Bank of New York Staff Report No. 700.

Bos, M., Breza, E., \& Liberman, A. (2018). The labor market effects of credit market information. The Review of Financial Studies, 31(6), 2005-2037.

Castleman, B. L. and Page, L. C. (2016). Freshman year financial aid nudges: An experiment to increase FAFSA renewal and college persistence. Journal of Human Resources, 51(2): 389-415.

Conqvist, H. and Thaler, R. H. (2004). Design choices in privatized social-security systems: Learning from the Swedish experience. American Economic Review, 94(2):424-428.

Cohen-Cole, E., Herkenhoff, K., \& Phillips, G. (2016). The Impact of Consumer Credit Access on Employment, Earnings and Entrepreneurship. NBER Working Paper.

Cronqvist, H. and Thaler, R. (2004). Design Choices in Privatized Social-Security Systems: Learning from the Swedish Experience. American Economic Review, vol. 94, issue 2, 424-428.

Dobbie, W., Goldsmith-Pinkham, P., Mahoney, N., \& Song, J. (2016). Bad credit, no problem? Credit and labor market consequences of bad credit reports. NBER working paper \#w22711.

Dynarski, S. \& Kreisman, D. (2013). "Loans for Educational Opportunity: Making Borrowing Work for Today's Students." The Hamilton Project at the Brookings Institution. 
Eckel C., Grossman P. (2002). Sex differences and statistical stereotyping in attitudes toward financial risk. Evolution and Human Behavior 23(4): 281-295.

Eckel C. C., Grossman P. J. (2008). Forecasting risk attitudes: An experimental study using actual and forecast gamble choices. Journal of Economic Behavior \& Organization 68(1): 1-7.

Field, E. (2009). Educational debt burden and career choice: evidence from a financial aid experiment at NYU law school. American Economic Journal: Applied Economics, 1(1), 1-21.

Findeisen, S., \& Sachs, D. (2016). Education and optimal dynamic taxation: The role of incomecontingent student loans. Journal of Public Economics, 138, 1-21.

Gary-Bobo, R. J., \& Trannoy, A. (2015). Optimal student loans and graduate tax under moral hazard and adverse selection. The RAND Journal of Economics, 46(3), 546-576.

Gaulke, A. P., and Reynolds C. (2018). “Student Loan Repayment.” Working paper.

Haan, T. and Linde, J. (2018). 'Good Nudge Lullaby': Choice Architecture and Default Bias Reinforcement. The Economic Journal, Vol. 128, Issue 610, 1180-1206.

Herbst, Daniel (2018). "Liquidity and Insurance in Student Loan Contracts: Estimating the Effects of Income-Driven Repayment on Default and Consumption." Working paper accessed 08/2018: https://drive.google.com/file/d/1A-gq_LIqffY6r2gDTcUK9-Y3ZV8Go6SU/view

Hershbein, B., Harris, B., and Kearney, M. (2014). Major decisions: Graduates' earnings growth and debt repayment. Washington, DC: Hamilton Project, Brookings Institution.

Ionescu, F. (2009). The federal student loan program: Quantitative implications for college enrollment and default rates. Review of Economic dynamics, 12(1), 205-231.

Johnson, E. J. and Goldstein, D. (2003). Do defaults save lives? Science, 302(5649): 1338-1339.

King, J. R., Mullainathan, S., Shafir, E., Vermeulen, L. and Wrobel, V. (2012). Comparison Friction: Experimental evidence from Medicare drug plans. Quarterly Journal of Economics, 127(1).

Klepfer, K. (2015). Informed or Overwhelmed? A Legislative History of Student Loan Counseling with a Literature Review on the Efficacy of Loan Counseling. Research Report. TG (Texas Guaranteed Student Loan Corporation).

Dynarski, S., \& Kreisman, D. (2013). Loans for educational opportunity: Making borrowing work for today's students. The Hamilton Project Discussion Paper, 5.

Lochner, L., \& Monge-Naranjo, A. (2016). Student loans and repayment: Theory, evidence, and policy. In Handbook of the Economics of Education (Vol. 5, pp. 397-478). Elsevier.

Looney, A., \& Yannelis, C. (2015). A crisis in student loans?: How changes in the characteristics of borrowers and in the institutions they attended contributed to rising loan defaults. Brookings Papers on Economic Activity, 2015(2), 1-89. 
Marx, B. M. and Turner, L. J (2018). Student Loan Nudges: Experimental Evidence on Borrowing and Educational Attainment. NBER Working Paper No. 24060.

Madrian, B. C. and Shea, D. F. (2001). The power of suggestion: Inertia in 401 (k) participation and savings behavior. Quarterly Journal of Economics, 116(4):1149-1187.

Mezza, A., Ringo, D., Sherland, S., \& Sommer, K. (2016). Student Loans and Homeownership. Finance and Economics Discussion Series Divisions of Research \& Statistics and Monetary Affairs Federal Reserve Board, Washington, D.C. Working Paper.

Mueller, H. M., \& Yannelis, C. (2018). The rise in student loan defaults in the Great Recession. Journal of Financial Economics.

National Public Radio. 2012. "Bad Credit Reports Affect Job Applicants." National Public Radio http://www.npr.org/2009/08/11/111769999/low-credit-scores-affect-job-applicants.

New York Times. 2013. "Employers Pull Applicants Credit Reports." The New York Times http://www.nytimes.com/2013/05/12/business/employers-pull-applicants-credit-reports.html.

Rothstein, J., \& Rouse, C. E. (2011). Constrained after college: Student loans and early-career occupational choices. Journal of Public Economics, 95(1-2), 149-163.

Samuelson, W., \& Zeckhauser, R. (1988). Status Quo Bias in Decision Making. Journal of Risk and Uncertainty, vol. 1, issue 1, 7-59.

SHRM. 2010. "Background Checking: The Implications of Credit Background Checks on the Decision to Hire or Not to Hire." Society for Human Resource Management.

Thaler, R. H. and Benartzi, S. (2004). Save more tomorrow: Using behavioral economics to increase employee saving. Journal of political Economy, 112(S1):S164-S187.

Thaler, R. H. and Sunstein, C. R (2003). Libertarian Paternalism. American Economic Review, Vol. 93, No. 2, 175-179.

U.S. Government Accountability Office (2015). Federal student loans: education could do more to help ensure borrowers are aware of repayment and forgiveness options. GAO-15-663.

U.S. Government Accountability Office (2016). Education needs to improve its income driven repayment plan budget estimates. Technical Report GAO-17-22.

Winter, J., Balza, R., Caro, F., Heiss, F., Jun, B.-h., Matzkin, R., and McFadden, D. (2006). Medicare prescription drug coverage: Consumer information and preferences. Proceedings of the National Academy of Sciences, 103(20):7929-7934

Wiswal, M. and Zafar, B. (2015). Determinants of College Major Choice: Identification using an Information Experiment. The Review of Economic Studies, Vol. 82, Issue 2, 791-824.

Yannelis, C. (2017). Strategic default on student loans. Working Paper. Downloaded from http://faculty.chicagobooth.edu/workshops/financelunch/past/pdf/Strategic\%20Default.pdf. 


\section{Tables}

Table 1: Simulated earnings differences and standard deviations vs. standard plan

Difference from Standard Plan

\begin{tabular}{lccc} 
& Earnings-Repayments & Difference of 1 s.d. & Prob(Default) \\
\hline Standard & $\$ 0$ & $\$ 0$ & 0.35 \\
Graduated & $-\$ 375$ & $-\$ 1,272$ & 0.35 \\
REPAYE & $\$ 14,734$ & $-\$ 17,296$ & 0 \\
PAYE/IBR-New & $\$ 14,561$ & $-\$ 18,359$ & 0 \\
ICR & $\$ 8,916$ & $-\$ 12,456$ & 0 \\
\hline
\end{tabular}

Notes: Table shows expected difference in earnings less repayments compared with Standard repayment plan (column 1) and expected standard deviation differences (column 2) from Standard plan (this is sd(plan)$\operatorname{sd}($ standard)). Simulated earnings draws pre-tax income from work ventiles from distribution of four-year college graduates age 24 in 2015 . Earnings then grow for 25 years assuming a quartic growth rate estimated from empirical cross-section in same year. Earnings are reduced by $10 \%$ in each year following repayment default (only possible for Standard and Graduated). 
Table 2. Student loan experiment treatments

\begin{tabular}{|c|c|c|c|c|c|}
\hline Treatment & Default plan & $\begin{array}{l}\text { Informational } \\
\text { environment }\end{array}$ & $\begin{array}{l}\text { Earnings } \\
\text { information }\end{array}$ & Skip option & Name change \\
\hline \multicolumn{6}{|c|}{ Main Treatment Cells } \\
\hline T 1 (Baseline) & Standard & Complex & & & \\
\hline Т 2 & REPAYE & Complex & & & \\
\hline Т 3 & Standard & Complex & Yes & & \\
\hline $\mathrm{T} 4$ & REPAYE & Complex & Yes & & \\
\hline T 5 & Standard & Simple & & & \\
\hline Т 6 & REPAYE & Simple & & & \\
\hline $\mathrm{T} 7$ & Standard & Simple & Yes & & \\
\hline Т 8 & REPAYE & Simple & Yes & & \\
\hline \multicolumn{6}{|c|}{ Additional Treatment Cells } \\
\hline T 9 & Standard & Complex & & Yes & \\
\hline $\mathrm{T} 10$ & REPAYE & Complex & & Yes & \\
\hline $\mathrm{T} 11$ & Standard & Simple & Yes & Yes & \\
\hline $\mathrm{T} 12$ & REPAYE & Simple & Yes & Yes & \\
\hline $\mathrm{T} 13$ & Standard & Complex & & & "Fixed" \\
\hline Т 14 & REPAYE & Complex & & & "Fixed" \\
\hline
\end{tabular}

Table shows all treatment cells. 
Table 3. Subject summary statistics

\begin{tabular}{|c|c|c|}
\hline & Mean & s.d. \\
\hline Male & 0.38 & $(0.48)$ \\
\hline Age & 20.6 & $(2.32)$ \\
\hline White & 0.10 & $(0.30)$ \\
\hline Black & 0.61 & $(0.49)$ \\
\hline Hispanic & 0.04 & $(0.21)$ \\
\hline Asian & 0.13 & $(0.34)$ \\
\hline Other & 0.11 & $(0.31)$ \\
\hline Year 2-5 & 0.98 & $(0.14)$ \\
\hline Has loans & 0.73 & $(0.44)$ \\
\hline \multicolumn{3}{|l|}{ School } \\
\hline Business & 0.27 & $(0.44)$ \\
\hline Arts \& Sci. & 0.49 & $(0.50)$ \\
\hline Policy & 0.08 & $(0.28)$ \\
\hline Health & 0.08 & $(0.26)$ \\
\hline Other & 0.09 & $(0.28)$ \\
\hline Obs. & \multicolumn{2}{|c|}{542} \\
\hline
\end{tabular}

Notes: Table shows means (sd) for subjects in the experiment. All measures are self-reported. 
Table 4: Experimental and actual take-up rates.

\begin{tabular}{lccc}
\hline & GAO (2016) & GAO (2015) & Baseline \\
\hline Standard & 0.76 & 0.65 & 0.63 \\
Graduated & 0.24 & 0.14 & 0.13 \\
IDR plans & n/a & 0.19 & 0.25 \\
Other & 0.02 & $\mathrm{n} / \mathrm{a}$ \\
\hline Notes: Columns 1 and 2 show the distribution of repayment plans for borrowers with outstanding \\
balances as of 2013-2016 (column 1) and 2014 (column2) from two GAO reports (GAO 215, 2016). \\
Column 3 shows results from our Baseline specification.
\end{tabular}


Table 5: Repayment choices under full information.

\begin{tabular}{lccccc}
\hline & Standard & REPAYE & Graduated & Other IDR & $\mathrm{N}$ \\
\hline T1. Baseline & 0.625 & 0.075 & 0.125 & 0.175 & 40 \\
& $(0.490)$ & $(0.267)$ & $(0.335)$ & $(0.385)$ & \\
T2. REPAYE Default & 0.342 & 0.316 & 0.237 & 0.105 & 38 \\
& $(0.481)$ & $(0.471)$ & $(0.431)$ & $(0.311)$ & \\
T3. Earnings Information & 0.538 & 0.205 & 0.128 & 0.128 & 39 \\
& $(0.505)$ & $(0.409)$ & $(0.339)$ & $(0.339)$ & \\
T4. REPAYE Default & 0.162 & 0.378 & 0.324 & 0.135 & 37 \\
$\quad$ + Earnings Information & $(0.374)$ & $(0.492)$ & $(0.475)$ & $(0.347)$ & \\
\hline
\end{tabular}

Table shows distribution (mean, sd) of repayment choices under full information. 
Table 6: Effects of changing the default and information on repayment choice

\begin{tabular}{|c|c|c|c|}
\hline & \multicolumn{3}{|c|}{ Treatment } \\
\hline & T2. REPAYE Default & T3. Earnings Info & $\begin{array}{l}\text { T4. REPAYE Default } \\
\text { \& Earnings Info }\end{array}$ \\
\hline \multicolumn{4}{|c|}{ Panel A: Unadjusted } \\
\hline Standard & $\begin{array}{c}-0.259^{* * *} \\
(0.095)\end{array}$ & $\begin{array}{l}-0.0967 \\
(0.099)\end{array}$ & $\begin{array}{c}-0.470^{* * *} \\
(0.097)\end{array}$ \\
\hline REPAYE & $\begin{array}{l}0.271 * * \\
(0.113)\end{array}$ & $\begin{array}{c}0.190 \\
(0.122)\end{array}$ & $\begin{array}{c}0.337 * * * \\
(0.108)\end{array}$ \\
\hline Graduated & $\begin{array}{l}0.0723 \\
(0.093)\end{array}$ & $\begin{array}{r}-0.0347 \\
(0.107)\end{array}$ & $\begin{array}{l}0.156^{*} \\
(0.085)\end{array}$ \\
\hline Other IDR & $\begin{array}{r}-0.0842 \\
(0.076)\end{array}$ & $\begin{array}{r}-0.0589 \\
(0.075)\end{array}$ & $\begin{array}{l}-0.024 \\
(0.066)\end{array}$ \\
\hline Obs. & & 154 & \\
\hline Panel B: With & & & \\
\hline Standard & $\begin{array}{c}-0.274 * * * \\
(0.094)\end{array}$ & $\begin{array}{l}-0.0428 \\
(0.100)\end{array}$ & $\begin{array}{c}-0.400 * * * \\
(0.099)\end{array}$ \\
\hline REPAYE & $\begin{array}{c}0.293 * * * \\
(0.111)\end{array}$ & $\begin{array}{l}0.211^{*} \\
(0.120)\end{array}$ & $\begin{array}{c}0.361 * * * \\
(0.107)\end{array}$ \\
\hline Graduated & $\begin{array}{l}0.0938 \\
(0.091)\end{array}$ & $\begin{array}{r}-0.0492 \\
(0.102)\end{array}$ & $\begin{array}{l}0.154^{*} \\
(0.085)\end{array}$ \\
\hline Other IDR & $\begin{array}{l}-0.113 \\
(0.074)\end{array}$ & $\begin{array}{l}-0.119 \\
(0.073)\end{array}$ & $\begin{array}{l}-0.114 \\
(0.071)\end{array}$ \\
\hline Demographics & $\mathrm{x}$ & $\mathrm{x}$ & $\mathrm{x}$ \\
\hline Risk & $\mathrm{x}$ & $\mathrm{x}$ & $\mathrm{x}$ \\
\hline School FE & $\mathrm{x}$ & $\mathrm{x}$ & $\mathrm{x}$ \\
\hline Session FE & $\mathrm{x}$ & $\mathrm{x}$ & $\mathrm{x}$ \\
\hline Obs. & & 154 & \\
\hline
\end{tabular}


Table 7: Effect of default and information under simple choices and information.

\begin{tabular}{|c|c|c|c|c|c|}
\hline & \multicolumn{3}{|c|}{ Means } & \multicolumn{2}{|c|}{ Regression } \\
\hline & \multirow{2}{*}{$\begin{array}{c}\text { Standard } \\
\text { (1) }\end{array}$} & \multirow{2}{*}{$\begin{array}{c}\text { REPAYE } \\
(2)\end{array}$} & \multirow[t]{2}{*}{$\mathrm{N}$} & \multicolumn{2}{|c|}{ Dep. Var. $=1[$ Standard $]$} \\
\hline & & & & $(3)$ & (4) \\
\hline T5. Simple Baseline & 0.579 & 0.421 & 38 & & \\
\hline & $(0.500)$ & $(0.500)$ & & & \\
\hline T6. REPAYE Default, Simple & 0.553 & 0.447 & 38 & -0.0263 & -0.0666 \\
\hline & $(0.504)$ & $(0.504)$ & & $(0.115)$ & $(0.121)$ \\
\hline T7. Earnings Information, & $\begin{array}{l}0.605 \\
(0495)\end{array}$ & $\begin{array}{c}0.395 \\
(0495)\end{array}$ & 38 & $\begin{array}{l}0.0263 \\
(0.114)\end{array}$ & $\begin{array}{l}-0.0232 \\
(0.115)\end{array}$ \\
\hline T8. REPAYE Default & 0.333 & 0.667 & 39 & $-0.246^{* *}$ & $-0.312 * * *$ \\
\hline + Earnings Information & $(0.478)$ & $(0.478)$ & & $(0.112)$ & $(0.112)$ \\
\hline Simple & & & & & \\
\hline \multicolumn{6}{|l|}{ Regression controls } \\
\hline Demographics & & & & & $\mathrm{x}$ \\
\hline Risk & & & & & $\mathrm{x}$ \\
\hline School FE & & & & & $\mathrm{x}$ \\
\hline Session FE & & & & & $\mathrm{x}$ \\
\hline Obs. & & & & 153 & 153 \\
\hline
\end{tabular}

Notes: Columns 1 and 2 show share choosing Standard and REPAYE across treatment cells (means, sd). Columns 3 and 4 show effects of each treatment relative to Baseline from a linear probability model.

Dependent variable $=1$ if subject chose Standard. Robust standard errors in parentheses. 
Table 8: Differences by risk preference (higher risk = less risk averse).

\begin{tabular}{|c|c|c|c|c|c|c|}
\hline & \multicolumn{3}{|c|}{ Dep. Var. = Any IDR } & \multicolumn{3}{|c|}{ Dep. Var. = Standard } \\
\hline & $(1)$ & (2) & (3) & (4) & (5) & $(6)$ \\
\hline \multirow[t]{2}{*}{ Risk (centered) } & 0.014 & -0.043 & -0.048 & -0.011 & 0.024 & 0.040 \\
\hline & $(0.026)$ & $(0.045)$ & $(0.052)$ & $(0.025)$ & $(0.048)$ & $(0.054)$ \\
\hline \multirow[t]{2}{*}{ T2. REPAYE Default } & 0.173 & 0.172 & 0.143 & $-0.285 * *$ & $-0.279 * *$ & $-0.261 * *$ \\
\hline & $(0.108)$ & $(0.108)$ & $(0.112)$ & $(0.111)$ & $(0.112)$ & $(0.111)$ \\
\hline \multirow[t]{2}{*}{ T3. Earnings Info } & 0.085 & 0.098 & 0.061 & -0.088 & -0.099 & -0.022 \\
\hline & $(0.104)$ & $(0.101)$ & $(0.116)$ & $(0.112)$ & $(0.111)$ & $(0.120)$ \\
\hline \multirow[t]{2}{*}{ T4. REPAYE + Info } & $0.260 * *$ & $0.265 * *$ & $0.204 *$ & $-0.460 * * *$ & $-0.461 * * *$ & $-0.388 * * *$ \\
\hline & $(0.109)$ & $(0.110)$ & $(0.117)$ & $(0.100)$ & $(0.101)$ & $(0.111)$ \\
\hline \multirow[t]{2}{*}{ Risk*(T2. REPAYE) } & & 0.053 & 0.044 & & -0.004 & -0.003 \\
\hline & & $(0.065)$ & $(0.071)$ & & $(0.071)$ & $(0.073)$ \\
\hline \multirow[t]{2}{*}{ Risk*(T3. Earnings Info) } & & $0.189 * * *$ & $0.180 * *$ & & $-0.150 * *$ & -0.133 \\
\hline & & $(0.068)$ & $(0.084)$ & & $(0.074)$ & $(0.085)$ \\
\hline \multirow[t]{2}{*}{ Risk*(T4. REPAYE + Info) } & & 0.035 & 0.039 & & -0.029 & -0.058 \\
\hline & & $(0.072)$ & $(0.081)$ & & $(0.063)$ & $(0.070)$ \\
\hline Demographics & & & $\mathrm{X}$ & & & $\mathrm{X}$ \\
\hline School FE & & & $\mathrm{X}$ & & & $\mathrm{X}$ \\
\hline Session FE & & & $\mathrm{X}$ & & & $\mathrm{X}$ \\
\hline Obs. & 154 & 154 & 154 & 154 & 154 & 154 \\
\hline
\end{tabular}


Table 9: Patterns of skipping counseling.

\begin{tabular}{lccccc}
\hline & \multicolumn{2}{c}{ Complex } & \multicolumn{2}{c}{ Simple } \\
\cline { 2 - 5 } & $\begin{array}{c}\text { T9. } \\
\text { Baseline } \\
\text { Can Skip }\end{array}$ & $\begin{array}{c}\text { T10. } \\
\text { REPAYE } \\
\text { Can Skip }\end{array}$ & $\begin{array}{c}\text { T11. } \\
\text { Baseline }+ \\
\text { Earnings } \\
\text { Can Skip }\end{array}$ & $\begin{array}{c}\text { T12. } \\
\text { REPAYE }+ \\
\text { Earnings } \\
\text { Can Skip }\end{array}$ & Total \\
\hline Did not skip & 0.74 & 0.77 & 0.82 & 0.89 & 0.81 \\
Skipped before counseling & 0.10 & 0.03 & 0.03 & 0.00 & 0.04 \\
Skipped on pages 1 or 2 & 0.08 & 0.21 & 0.15 & 0.11 & 0.14 \\
Skipped on pages 3 or 4 & 0.08 & 0 & 0 & 0 & 0.02 \\
\hline Obs. & 39 & 39 & 39 & 38 & 155 \\
\hline Notes: Table shows patterns of skipping exit counseling under treatments where subjects were given \\
the opportunity to skip and could leave when finished. Page 2 of exit counseling is where \\
subjects/borrowers see repayment options and can select a plan.
\end{tabular}


Table 10: Distribution of repayment choices when subjects can skip counseling.

\begin{tabular}{|c|c|c|c|c|c|}
\hline \multirow[b]{2}{*}{ Complex information } & Standard & REPAYE & Graduated & Other IRD & Obs. \\
\hline & & & & & \\
\hline T1. Baseline & $\begin{array}{c}0.625 \\
(0.490)\end{array}$ & $\begin{array}{c}0.075 \\
(0.267)\end{array}$ & $\begin{array}{c}0.125 \\
(0.335)\end{array}$ & $\begin{array}{c}0.175 \\
(0.385)\end{array}$ & 40 \\
\hline T9. Baseline + Skip Option & $\begin{array}{c}0.744 \\
(0.442)\end{array}$ & $\begin{array}{c}0.103 \\
(0.307)\end{array}$ & $\begin{array}{c}0.026 \\
(0.160)\end{array}$ & $\begin{array}{c}0.128 \\
(0.339)\end{array}$ & 39 \\
\hline T9. Non-Skippers & $\begin{array}{c}0.655 \\
(0.484)\end{array}$ & $\begin{array}{c}0.138 \\
(0.351)\end{array}$ & $\begin{array}{c}0.034 \\
(0.186)\end{array}$ & $\begin{array}{c}0.172 \\
(0.384)\end{array}$ & 29 \\
\hline T2. REPAYE Default & $\begin{array}{c}0.162 \\
(0.374)\end{array}$ & $\begin{array}{c}0.378 \\
(0.492)\end{array}$ & $\begin{array}{c}0.324 \\
(0.475)\end{array}$ & $\begin{array}{c}0.135 \\
(0.347)\end{array}$ & 37 \\
\hline T10. REPAYE + Skip Option & $\begin{array}{c}0.179 \\
(0.389)\end{array}$ & $\begin{array}{c}0.538 \\
(0.505)\end{array}$ & $\begin{array}{c}0.103 \\
(0.307)\end{array}$ & $\begin{array}{c}0.179 \\
(0.389)\end{array}$ & 39 \\
\hline T10. Non-Skippers & $\begin{array}{c}0.233 \\
(0.430)\end{array}$ & $\begin{array}{c}0.400 \\
(0.498)\end{array}$ & $\begin{array}{c}0.133 \\
(0.346)\end{array}$ & $\begin{array}{c}0.233 \\
(0.430)\end{array}$ & 30 \\
\hline \multicolumn{6}{|l|}{ Simple Information } \\
\hline T7. Baseline, Simple + Earn Info & $\begin{array}{c}0.579 \\
(0.500)\end{array}$ & $\begin{array}{c}0.421 \\
(0.500)\end{array}$ & & & 38 \\
\hline $\begin{array}{l}\text { T11. Baseline Simple + Earn Info } \\
+ \text { Skip Option }\end{array}$ & $\begin{array}{c}0.718 \\
(0.456)\end{array}$ & $\begin{array}{c}0.282 \\
(0.456)\end{array}$ & & & 39 \\
\hline T11. Non-Skippers & $\begin{array}{c}0.656 \\
(0.483)\end{array}$ & $\begin{array}{c}0.344 \\
(0.483)\end{array}$ & & & 32 \\
\hline T8. REPAYE, Simple + Earnings & $\begin{array}{c}0.333 \\
(0.478)\end{array}$ & $\begin{array}{c}0.667 \\
(0.478)\end{array}$ & & & 39 \\
\hline $\begin{array}{l}\text { T12. REPAYE, Simple }+ \text { Earnings }+ \\
\text { Skip Option }\end{array}$ & $\begin{array}{c}0.368 \\
(0.489)\end{array}$ & $\begin{array}{c}0.632 \\
(0.489)\end{array}$ & & & 38 \\
\hline T12. Non-Skippers & $\begin{array}{c}0.412 \\
(0.500)\end{array}$ & $\begin{array}{c}0.588 \\
(0.500)\end{array}$ & & & 34 \\
\hline
\end{tabular}

Notes: Table shows mean (sd) of repayment choices when subjects can and cannot skip exit counseling. 
Table 11: Effect of changing the name from "Standard" to "Fixed".

\begin{tabular}{lccccc}
\hline & Standard & REPAYE & Graduated & Other IDR & Obs. \\
\hline Baseline & 0.625 & 0.075 & 0.125 & 0.175 & 40 \\
& $(0.490)$ & $(0.267)$ & $(0.335)$ & $(0.385)$ & \\
Standard = Fixed & 0.525 & 0.175 & 0.125 & 0.175 & 40 \\
& $(0.506)$ & $(0.385)$ & $(0.335)$ & $(0.385)$ & \\
\hline & & & & & \\
REPAYE + & 0.162 & 0.378 & 0.324 & 0.135 & 37 \\
Earnings Info & $(0.374)$ & $(0.492)$ & $(0.475)$ & $(0.347)$ & \\
REPAYE + & 0.175 & 0.450 & 0.125 & 0.250 & 40 \\
Earnings Info + Fixed & $(0.385)$ & $(0.504)$ & $(0.335)$ & $(0.439)$ & \\
\hline
\end{tabular}

Table shows means and standard deviations across two identical treatments where only the name "Standard" is changed to "Fixed". 


\section{Figures}

Figure 1. Simulated earnings differences vs. standard plan

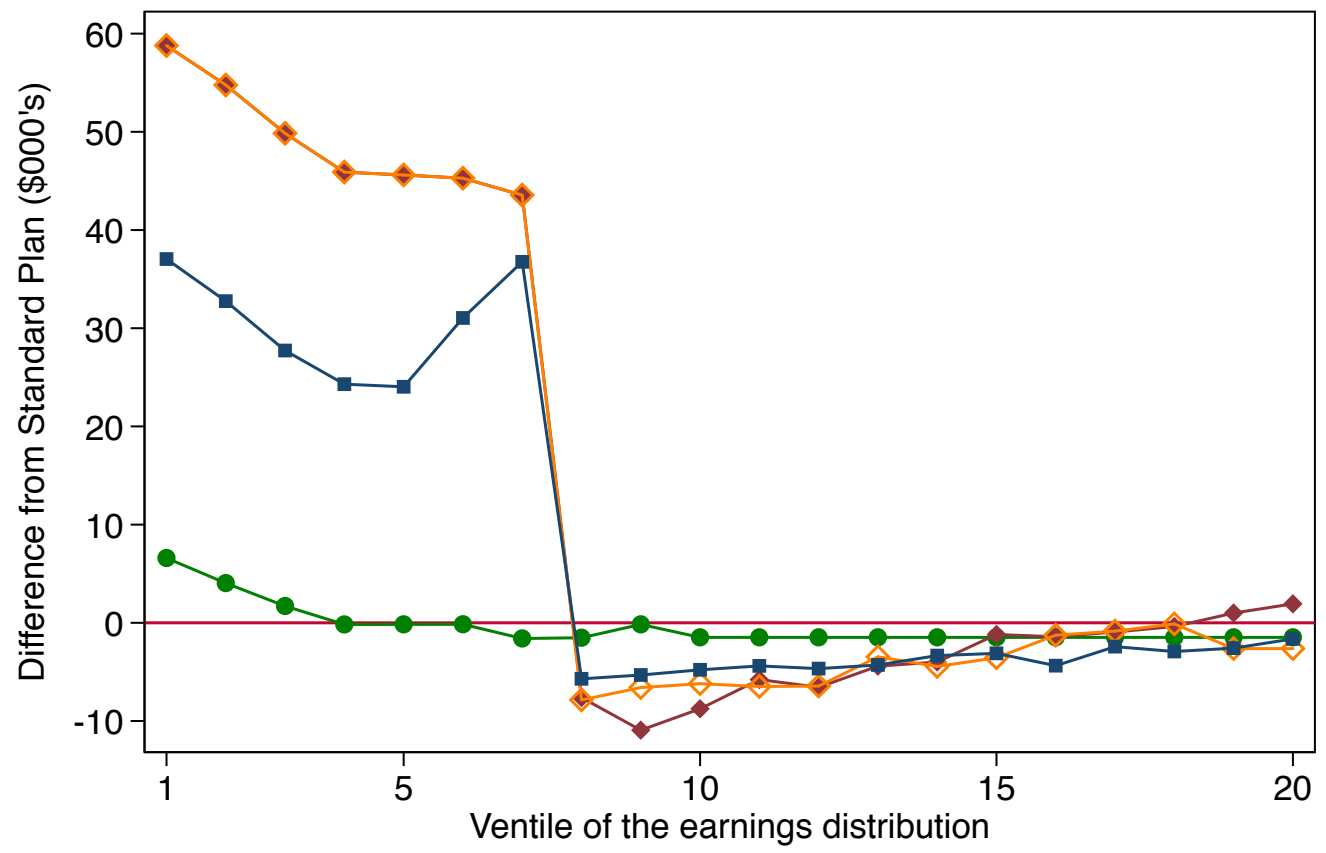

$\multimap$ Graduated $\multimap$ REPAYE $\diamond$ PAYE/IBR-new $\rightleftarrows$ ICR

Notes: Figure plots expected difference in earnings less repayments compared with Standard repayment plan by ventile of the earnings distribution. Simulated earnings draws pre-tax income from work ventiles from distribution of four-year college graduates age 24 in 2015. Earnings then grow for 25 years assuming a quartic growth rate estimated from empirical cross-section in same year. Earnings are reduced by $10 \%$ in each year following repayment default (only possible for Standard and Graduated). 
Figure 2. Experimental compensation vs. Standard plan
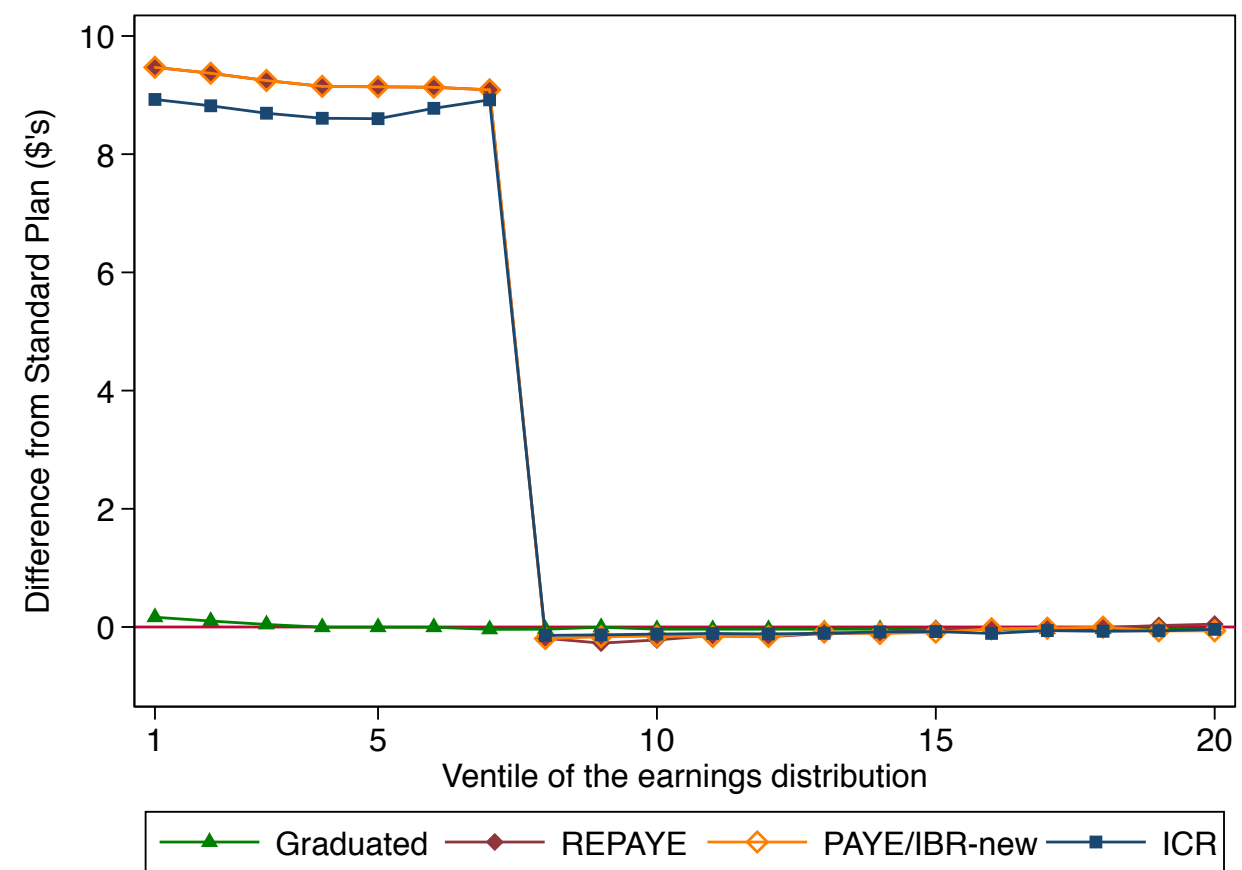

Notes: Figure plots expected difference in experimental compensation compared with Standard repayment plan by ventile of the earnings distribution. The exchange rate is $\$ 2.50$ per 100,000 earned in simulated lab earnings. Subjects begin with an $\$ 8$ U.S endowment which subjects lose if they default. 
Figure 3. Effect of information about earnings on earnings expectations

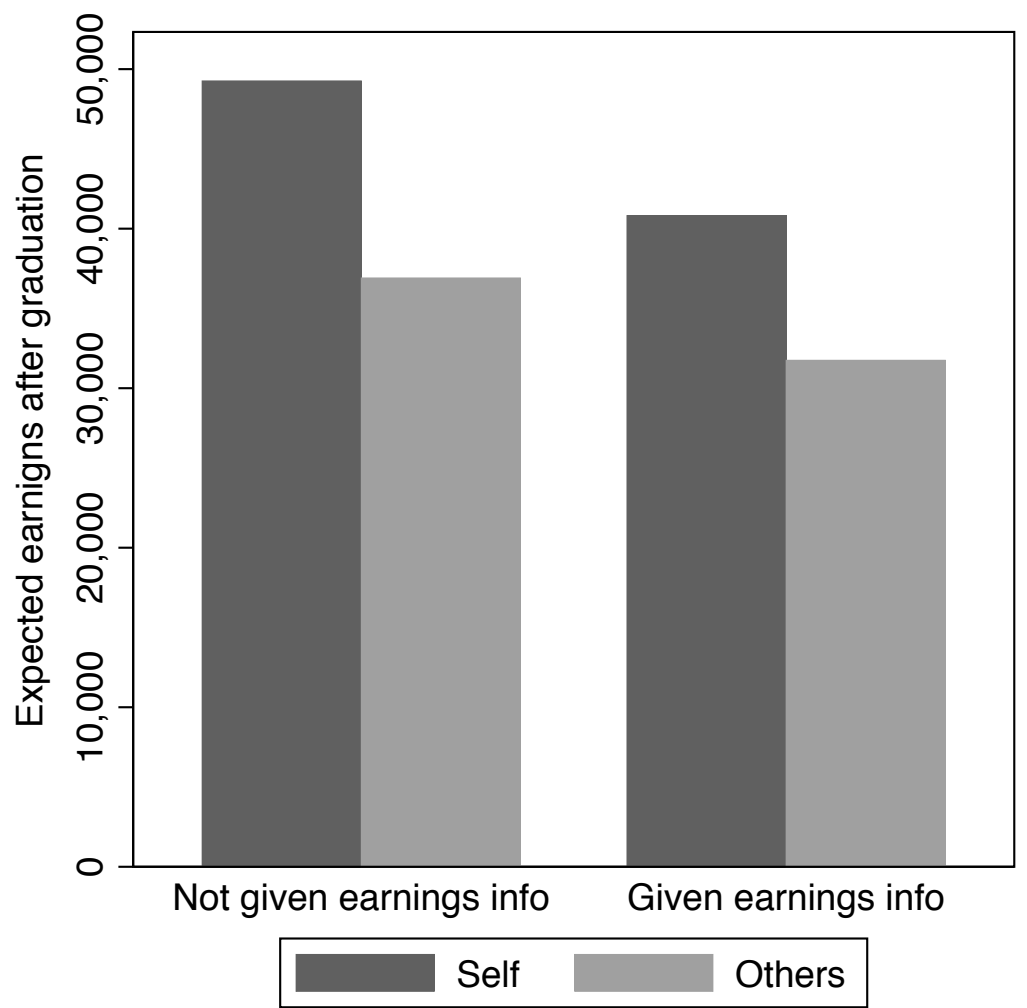

Notes: Figure shows mean responses to question what do you (others) expect to earn in the first year after graduation. Left two bars show means for subjects who did not receive information about the distribution of earnings. The right bars show means for those who received this information as part of treatment. 


\section{Appendix}

\section{A1. Subject instructions.}

\section{Instructions}

In the following you will experience a simulation of the federal government's Student Loan Exit Counseling in which students learn about student loan repayment options and can choose a repayment plan. For our purposes, we will assume you have a direct subsidized student loan of $\$ 23,000$ at an interest rate of $4.6 \%$.

Your payment for participation in this study will come from "lab earnings" taken over 25 "lab years." These "lab earnings" are designed to reflect a random draw from the distribution of what actual recent college graduates with a Bachelor's degree might expect to earn over each of the next 25 years.

To create your "lab earnings", we begin by dividing the distribution of pre-tax earnings from work for 24 year olds in the U.S. with a Bachelor's degree into 20 representative individuals. You are then randomly assigned to be one of these individuals - thus you have an equal chance of being in the bottom, middle or top of the earnings distribution. You will then receive what a typical individual at that place in the distribution might expect to earn each year for each of 25 "lab years."

At the end of each "lab year" we first calculate your "discretionary earnings" by subtracting from your "lab earnings" basic living expenses, which we set equal to $150 \%$ of the current federal poverty line, and withholding for Social Security and Medicare. From this we then subtract payments due on your student loan until the loan is either paid off or, in some cases, forgiven. The remainder (your "discretionary earnings" less any loan repayment) you will keep. These remaining "lab earnings" will be converted into real U.S. dollars at a rate of $\$ 2.50$ per 100,000 "lab dollars" earned.

In addition, you will start the study with a gift of $\$ 8$ real U.S. dollars.

If in any "lab year" your "discretionary earnings" are less than what you are required to repay on your student loan, your loan will go into default. If you default on your loan, you will receive a penalty in the loss of your $\$ 8$ U.S. dollar gift in addition to a $10 \%$ penalty on all future "lab earnings" thereafter.

\section{Summary}

- You begin with a direct subsidized loan of $\$ 23,000$ at $4.6 \%$ interest.

- You then complete the Student Loan Exit Counseling.

- You are then randomly assigned a stream of "lab earnings" drawn from the distribution of what 24 year old college graduates might expect to earn over each of the next 25 years.

- At the end of each "lab year" basic living expenses and federal withholdings are deducted from your "lab earnings" first, then payments on student loans are deducted if any balance remains. The remaining "lab earnings" you keep.

- These are converted into real U.S. dollars at an exchange rate of $\$ 2.50$ for every 100,000 "lab dollars" you have left over in each year.

- If in any "lab year" you default on your student loan repayment because you cannot make your payment, you forfeit your $\$ 8$ gift and all future "lab earnings" are reduced by $10 \%$.

- You will learn your "earnings" draws after completing the Exit Counseling.

If you have any questions, please raise your hand and someone will approach you and answer your question. When you're ready to begin, please click on the Begin button at the bottom of this page. You may take as much time as you want to obtain information from the Exit Counseling site. 


\section{A2. Repayment options on facsimile exit counseling website.}

Your repayment plan is the Standard plan unless you change your plan by clicking on the other radio buttons below.

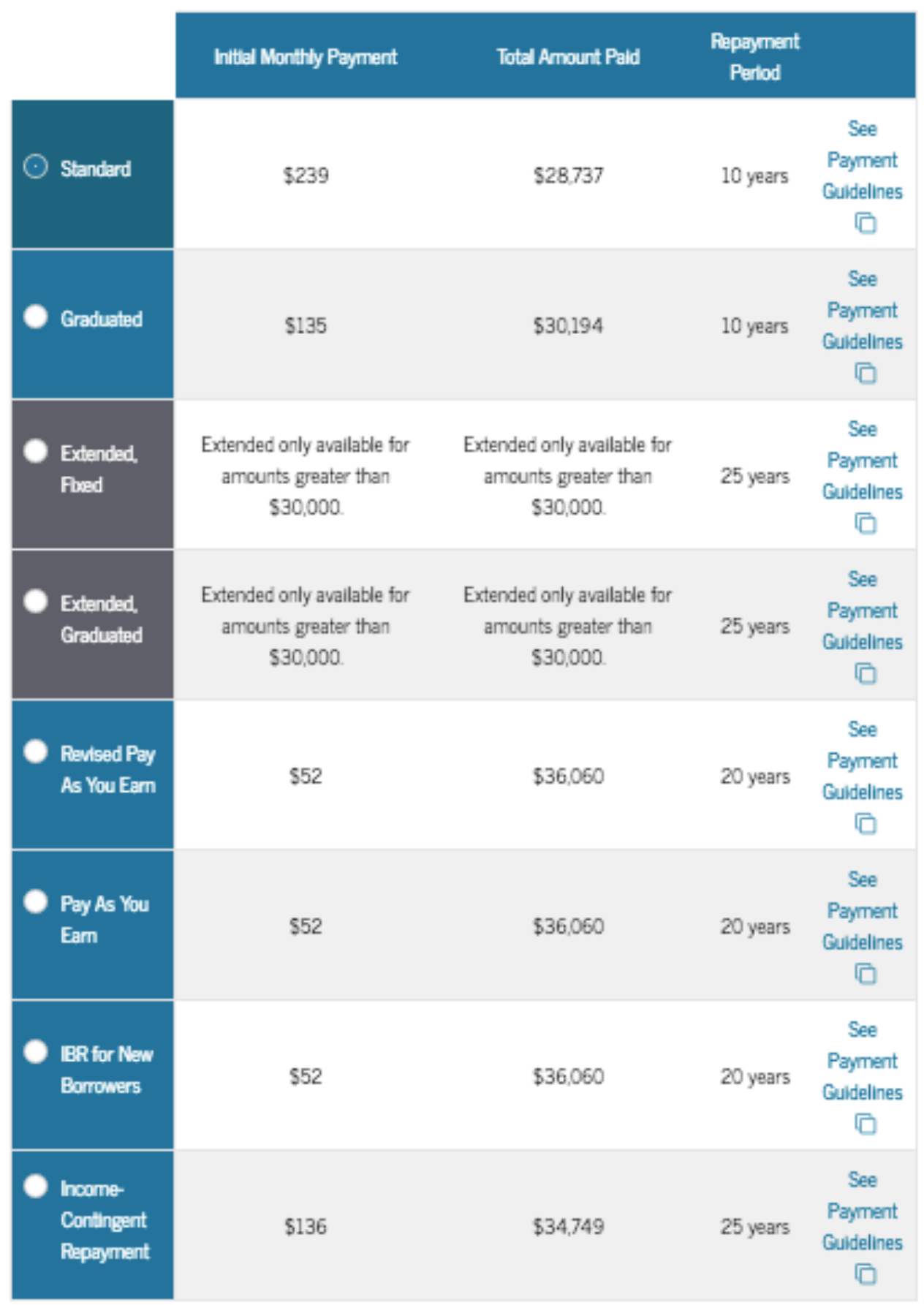

- These estimated monthly payments are based on your inputs and may not be exact Contact your loan servicer to see if you qualify for an income-driven repayment plan.

Notes: Image shows repayment options as seen by subjects. A value of $\$ 24,000$ was entered as expected earnings after college in order to create initial monthly and total payments. 


\section{A3. Earnings information on facsimile website.}

\section{Estimate What You Will Owe, Spend, and Earn}

In the sections below, enter what you expect to earn annually once you graduate.

How much did recent college graduates with a Bachelor's Degree (age 24) earn in $2015 ?$

- On average, recent graduates with a Bachelor's Degree earned about $\$ 22,000$ annually or $\$ 1,850$ per month last year in wages.

- More than $30 \%$ earned less than $150 \%$ of the federal poverty line.

- Over half of recent college graduates earned less than $\$ 24,000$ annually or 2,000 per month.

- Over $30 \%$ of recent college graduates had no discretionary income.

Annual income for recent college graduates in 2015.

\begin{tabular}{|r|c|c|c|c|}
\hline & Annual Income & Annual Discretionary hcome & Monthly hcome & Monthly Discretionary hcome \\
\hline Bottom 10\% & $\$ 700$ & $\$ 0$ & $\$ 58$ & $\$ 0$ \\
\hline Bottom 20\% & $\$ 5,800$ & $\$ 0$ & $\$ 483$ & $\$ 0$ \\
\hline Bottom 30\% & $\$ 11,700$ & $\$ 0$ & $\$ 975$ & $\$ 0$ \\
\hline Bottom 40\% & $\$ 17,650$ & $\$ 200$ & $\$ 1,471$ & $\$ 17$ \\
\hline Bottom 50\% & $\$ 23,150$ & $\$ 3,850$ & $\$ 1,929$ & $\$ 321$ \\
\hline Top 50\% & $\$ 28,700$ & $\$ 9,000$ & $\$ 2,392$ & $\$ 750$ \\
\hline Top 40\% & $\$ 33,550$ & $\$ 13,500$ & $\$ 2,796$ & $\$ 1,125$ \\
\hline Top 30\% & $\$ 39,800$ & $\$ 19,250$ & $\$ 3,317$ & $\$ 1,604$ \\
\hline Top 20\% & $\$ 47,350$ & $\$ 26,250$ & $\$ 3,946$ & $\$ 2,188$ \\
\hline Top 10\% & $\$ 70,850$ & $\$ 47,900$ & $\$ 5,904$ & $\$ 3,992$ \\
\hline
\end{tabular}

How are income, discretionary income and repayment related?

- Your discretionary income is what you have left after basic INing expenses have been taken out.

- Repayment under some plans is only required if your discretionary income is greater than 0 .

- About 9 out of 20 college graduates $(\mathbf{4 5 \%})$ had monthly discretionary income less than $\mathbf{\$ 2 4 0}$ at age 24 .

Notes: Image shows screen shot of information provided to subjects in treatment cells that provided information about the distribution of earnings for recent college graduates. 


\section{A4. Simplified Information on facsimile website}

\section{Your repayment plan is the Standard plan unless you change your plan by clicking on the other radio buttons below.}

\begin{tabular}{|c|c|c|}
\hline & Initial Monthly Payment & Repayment Period \\
\hline Standard & $\$ 28,737$ & 10 years \\
\hline & \multicolumn{2}{|c|}{$\begin{array}{l}\text { Under the Standard Repayment Plan, the total amount you owe on your loan is divided into } \\
\text { monthly payments that you make for } 10 \text { years. } \\
\text { - The amount due is the same each month and depends on how much you borrowed } \\
\text { regardless of what you earn. } \\
\text { Benefits: } \\
\text { - If you make all scheduled payments you will pay less in total under this plan because you } \\
\text { accure less interest by paying back quickly. } \\
\text { - Payment are predictable and there is no need to show proof of income. } \\
\text { Drawbacks: } \\
\text { - Payments do not adjust to your income, so you may have trouble repaying if your earnings } \\
\text { - If you fail to make payments due to unemployment or low earnings, your loan will go into } \\
\text { - default. }\end{array}$} \\
\hline $\begin{array}{l}\text { Revised Pay As You } \\
\text { Earn }\end{array}$ & $\$ 0$ & 20 years \\
\hline & $\begin{array}{l}\text { Under REPAYE, your monthly payment is equal to } 10 \% \text { of you } \\
\text { less than } 150 \% \text { of the Federal Poverty Line, you do not owe ar } \\
\text { remaining unpaid balance after } 25 \text { years is forgiven. } \\
\text { Benefits: } \\
\text { - REPAYE provides insurance against unemployment or } \\
\text { - When you cannot afford to pay, no payments are due. } \\
\text { - Your loan is forgiven if you cannot pay it off in } 25 \text { years } \\
\text { Drawbacks: } \\
\text { - Making little or no payment in some years will add to t } \\
\text { - You may make payments for longer under this plan un } \\
\text { required minimum payments. }\end{array}$ & $\begin{array}{l}\text { inary Income. If you earn } \\
\text { ings. } \\
\text { choose to that time. Any } \\
\text { chount of interest. }\end{array}$ \\
\hline
\end{tabular}




\section{A5. Alternate subject instructions.}

You now have the option to participate in the Student Loan Exit Counseling.

If you decide to participate:

- You will have an opportunity to study student loan repayment plans and select a plan to pay off your loan.

You may also skip the Student Loan Exit Counseling. If you skip:

- You will be assigned a preselected repayment plan to pay off your loan.

At any time you can click on the "Skip Exit Counseling" button below or on any other page during the Exit Counseling to conclude student loan portion of the experiment:

- You will learn your "earnings" draws immediately after completing the Student loan Exit Counseling or clicking on "Skip Exit Counseling" button.

You can leave the experimental lab as soon as you see your final earnings on your screen. 